disease and the writing of 82 letters to consultants and hospitals concerning patients.

In all 70 patients were referred for a second opinion and 13 sent to hospital direct, as immediate emergencies. Of the visits, 16 were night-calls between 10 p.m. and 8 a.m.

An attempt has been made to classify the types of illness from which the patients were suffering, though it speedily became obvious that such a classification could, at best, be only a very rough one and that while certain categories could be clearly defined others tended to overlap considerably. A classification by systems of the body was also undertaken. The results are shown in tabular form below, excluding all midwifery.

\begin{tabular}{|c|c|c|c|c|c|}
\hline \multicolumn{3}{|l|}{ Illnesses } & \multicolumn{3}{|c|}{ Systems of the Body } \\
\hline $\begin{array}{l}\text { Acute general infections } \\
\text { Acute local infections } \\
\text { Chronic infections . } \\
\text { Traumatic conditions } \\
\text { Degenerative conditions } \\
\text { Constitutional diseases } \\
\text { Organic nervous disease } \\
\text { Functional nervous illness } \\
\text { Neoplasms } \\
\text { Allergic conditions . } 0 \\
\text { Fibrositis and allied states }\end{array}$ & $\begin{array}{l}\ldots \\
\because \\
\because \\
\cdots \\
\cdots \\
\cdots\end{array}$ & $\begin{array}{l}25 \cdot 8 \% \\
12 \cdot 7 \% \\
3 \cdot 1 \% \\
7 \cdot 7 \% \\
13 \cdot 9 \% \\
23 \cdot 2 \% \\
2 \% \% \\
6 \cdot 3 \% \\
1 \% \% \\
1 \cdot 6 \% \\
2 \cdot 7 \%\end{array}$ & $\begin{array}{l}\text { Cardiovascular system } \\
\text { Respiratory tract } \\
\text { Digestive tract } \\
\text { Skin .. } \\
\text { Bones and joints } \\
\text { Muscles } \\
\text { Central nervous syste } \\
\text { cluding functional } \\
\text { disorders) } \\
\text { Genito-urinary system } \\
\text { Glands of internal se } \\
\text { Connective tissues } \\
\text { Eyes .. } \\
\text { Ears .. } \\
\text { Throat } \\
\text { Haemapoietic system }\end{array}$ & 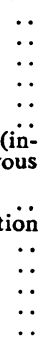 & $\begin{array}{l}9 \% \% \\
23.5 \% \\
14.8 \% \\
10 \cdot 5 \% \\
7 \% \% \\
4.1 \% \\
9.4 \% \\
\\
5.3 \% \\
1.5 \% \\
3 \% \% \\
1.9 \% \\
2.5 \% \\
6.7 \% \\
0.5 \%\end{array}$ \\
\hline
\end{tabular}

In respect of the original object of the survey-the estimation of the amount of neurotic illness-it rapidly became clear that quite apart from the clear-cut cases of almost pure neurosis a very large number of the patients suffering from a definite organic complaint were also affected by a strong subjective element, due to their anxiety about their health or anxiety about the effect of their illness on their economic conditions. In the table above the figure given for functional nervous disease of $6.3 \%$ tells only a part of the tale, as no patients with any demonstrable organic condition were included.

It seems obvious that the amount of neurotic illness seen by the general practitioner is very considerable, but that no reliable figure can be given inasmuch as standards of classification are almost impossible to set up, and the recognition of neurosis will in itself tend to vary with the outlook and temperament of the doctor himself.-I am, etc.,

Aldershot.

H. Bolton Tipler.

\section{True Hermaphroditism}

SIR,-Dr. A. P. Cawadias (Jan. 31, p. 229) would appear to be under some misunderstanding concerning the nature of hermaphroditism in the animal kingdom. Even the humble hermaphrodite worm might turn at being described as a "double animal." In reply to Dr. J. R. Edisbury (Dec. 27, 1947, p. 1056) it must be said that the whole subject is a very large one and it cannot be dismissed in a few lines.

As is well known, the sex of an animal depends primarily upon its genetic constitution-i.e., the sex-chromosomes when these are known to exist. But for the full development of a functioning sexual animal the whole hormonal apparatus is essential. Hormones and other conditions, however, can override the original sex chromosomes and cause a sex-reversal.

A definition of terms might not be out of place here. There are three groups:

1. True permanent hermaphrodites, in which ovary and testis remain together and function throughout life-e.g., earthworm

2. Sex reversals in which the animal starts as one sex and passes through a hermaphrodite stage to the other sex-e.g., the Buff Orpington hen (see below)

3. Those individuals with the gonads and sexual apparatus of one sex and some or all of the accessory organs and hence characters of the other sex-e.g., the mammalian intersexes.

Unisexuality is the primitive condition, and not hermaphroditism, as Dr. Cawadias suggests. For example, in the invertebrates it is the more specialized forms in any groups which exhibit this phenomenon, or where it occurs in a whole group this is entirely specialized. In the Crustacea the sessile barnacles are hermaphrodite and also many parasites. In general the phenomenon has evolved under conditions where fertilization would be difficult if unisexuality prevailed. It is not confined to such types, as is shown by the few vertebrate hermaphrodites such as the bony fish
Serranus, where a testis is present in the wall of the ovary and selffertilization takes place. These are all examples of Group 1 above.

Group 2 is illustrated by the now famous Buff Orpington hen which, after a blameless life of egg-laying and chick-rearing, at the age of $3 \frac{1}{2}$ years stopped laying, grew cock feathers, started crowing, and was successfully mated with a previously infertile Buff Orpington hen. At necropsy the ovary was found to be replaced by tumour tissue and a small amount of testicular tissue was presen in the ovary. This tissue had produced the viable sperm and incidentally the secondary sexual characters. This same effect may be produced by outside agents. The crustacean parasite Sacculina is able to convert a male crab into one with female characters. It has been shown that in doing so it is able to use the products of the "female" crab's metabolism for its own ends.

In the case of the worm Bonnelia, Baltzer (1925) has shown tha sex is determined by pure accident of situation. The larva at a certain stage sinks from the surface. If it falls near the proboscis of a female Bonnelia it becomes a male. If however it falls any where away from this influence it becomes a female. It has been shown that the female proboscis possesses a chemical substance which dominates the sexual character of the form which comes into contact with it.

Under Group 3 come all those cases in mammals, including man, which although predominantly of one sex do nevertheless exhibit certain characters of the other sex. In the case of cattle a co-twin to a male becomes a freemartin-i.e a female which never becomes a functional one. This has been shown to be due to the earlier elaboration of the male sex hormones by the male twin in utero (Lillie, 1917).

In all higher vertebrates both male and female ducts are present during development. In most cases one develops more rapidly than the other and only vestiges of the opposite sex are left. This is not, however, always so, and in some cases, in which one may postulate a time factor, much more of the organs of the other sex develops, and even the gonad may do so Hence the possibility of intersexes. These commonly occur in goats and pigs. In mice they are less common, and it may be suggested that here the sex-determining mechanism is more stable.

Goldschmidt (1931) in his work on moths has obtained evidence for the existence of "strong" and "weak" male and female genes. In his elaborate experiments he was able to breed types with varying grades of " maleness" and "femaleness." His theory suggests that sex and intersexuality are largely determined by a balance or lack of balance in the strength of these male and female genes. Whether this is applicable to vertebrates we do not know, but it may well be so.

Dr. Edisbury and others interested might consult any of the following books for a full account of this very large subject : Goldschmidt, R., The Mechanism and Physiology of Sex Deter mination (Methuen, 1923) ; Darlington, C. D., Recent Advances in Cytology (Churchill, 1937); Crew, F. A. E., Sex Determina tion (Methuen, 1933) ; Baker, J. R., Sex in Man and in Animals (Methuen, 1926).-I am, etc.

\section{King's College.}

Newcastle-upon-Tyne.

MARY A. WoOD,

\section{REFERENCES}

Baltzer, F. (1925). Publ. Staz. Zool. Napol., 6, 223.

Goldschmidt, R. (1931). Quart. Rev. Biol.

SIR,-I am indebted to Dr. A. P. Cawadias (Jan. 31, p. 229) for his informative iconoclasm and also for directing my attention to his Hermaphroditos, which I regret to say I have not yet read. In extenuation, your annotator (Nov. 22, 1947, p. 828) seems to have been in the same lamentable position.

There does not seem any immediate prospect of a convenient qualitative test for human $y$ chromosomes, or a roughly quantitative test for $x$, either of which would reveal the true or genetic sex. Perhaps someone who knows just what possibilities exist if any, will write an article on the subject, not forgetting the forensic aspects-e.g., male heirs, etc.-I am, etc.,

Hooton, Cheshire.

J. R. EDISBURY.

\section{Homoeopathy}

SIR,-My attention has just been drawn to Dr. D. W. Winnicott's letter (Feb. 14, p. 313) in which he states among other things that "homoeopathy has not been accepted by the profession on scientific grounds."

As a member of the profession who practises homoeopathy, may I point out to Dr. Winnicott that homoeopathy has never- 